\title{
PRODUKSI XANTHAN GUM SKALA PENGEMBANGAN MENGGUNAKAN LIMBAH PADAT TAPIOKA
}

\author{
Akhmad Endang Zainal Hasan ${ }^{1}$, Aton Yulianto², Ika Mulawati Purwanti Noviana² \\ dan Siwi Putri Andini ${ }^{1}$ \\ ${ }^{1}$ Departemen Biokimia, FMIPA-IPB Bogor \\ ${ }^{2}$ Kepala Balai Besar Teknologi Pati, BPPT \\ e-mail: pakzainalhasan@gmail.com, aytiara@yahoo.com, siwiputriandini90@gmail.com¹
}

\begin{abstract}
ABSTRAK
Xanthan gum merupakan polisakarida ekstra selular yang dihasilkan dari fermentasi dekstrosa oleh bakteri Xanthomonas campestris. Xanthan gum banyak digunakan dalam berbagai bidang industri sebagai stabilizer, pengental, dan pengemulsi. Dalam industri minyak, xanthan gum digunakan untuk mengentalkan lumpur pengeboran dan membawa potongan padatan akibat pengeboran kembali ke permukaan. Proses fermentasi dilakukan pada biofermentor dimana substansinya diletakkan pada waktu bersamaan. Berdasarkan pengamatan, diperoleh xanthan gum pada komposisi limbah padat tapioka tertinggi $50 \mathrm{~g} / \mathrm{L}$ dan urea $5 \mathrm{~g} / \mathrm{L}$. Optimasi dengan menggunakan Metode Permukaan Respon (RSM) dengan dua variabel yaitu limbah padat tapioka sebagai sumber karbon dan urea sebagai sumber nitrogen. Berdasarkan hasil perhitungan RSM, dapat disimpulkan bahwa setiap 16 jam respon maksimal mendekati titik pusat (0,0). Model memprediksi produksi xanthan gum optimal pada komposisi konsentrasi limbah padat tapioka sekitar $30 \mathrm{~g} / \mathrm{L}$ dan urea $5 \mathrm{~g} / \mathrm{L}$. Hasil antara nilai prediksi dan nilai sebenarnya menunjukkan model dalam penelitian ini layak dan efektif. Hasil uji reologi menunjukkan karakteristik produk yang baik yang didukung oleh uji FTIR yang menunjukkan spektrum yang sama antara xanthan gum dengan xanthan gum komersial.
\end{abstract}

Kata Kunci: Xanthan gum, Scale up, RSM, lumpur pengeboran

\begin{abstract}
Xanthan gum is an extra cellular polysaccharide produced from dextrose fermentation by Xanthomonas campestris. Xanthan gum is widely used in various industrial fields as a stabilizer, thickener, and emulsifier. In the oil industry, xanthan gum is used to thicken drilling mud and carry pieces of solids due to drilling back to the surface. The fermentation process is carried out on the biofermentor where the substance is placed at the same time. Based on observations, xanthan gum was obtained in the composition of the highest tapioca solid waste $50 \mathrm{~g} / \mathrm{L}$ and urea $5 \mathrm{~g} / \mathrm{L}$. Optimization using the Response Surface Method (RSM) with two variables namely tapioca solid waste as a source of carbon and urea as a nitrogen source. Based on the results of RSM calculations, it can be concluded that every 16 hours the maximum response approaches the center point $(0,0)$. The model predicts optimal xanthan gum production in the composition of the concentration of tapioca solid waste of about $30 \mathrm{~g} / \mathrm{L}$ and urea $5 \mathrm{~g} /$ $L$. The results between the predicted values and actual values indicate that the model is feasible and effective. The rheology test results showed good product characteristics supported by the FTIR test which showed the same spectrum between xanthan gum and commercial xanthan gum.
\end{abstract}

Keywords: Xanthan gum, Scale up, RSM, drilling mud

\section{PENDAHULUAN}

Xanthomonas campestris merupakan bakteri Gram negatif fitopatogenik pada tanaman pertanian yang berasal dari filum Proteobacteria dengan famili Xanthomonadacae. Xanthomonas campestris memiliki kemampuan untuk memproduksi gum xanthan yang berfungsi sebagai pelindung bakteri dari perubahan kondisi lingkungan, toksin, biosida, phagelitik, pagositosis, dll.
Xanthan gum banyak digunakan dalam berbagai bidang industri sebagai stabilizer, pengental, dan pengemulsi [1][2][3]. Tingginya viskositas dan kelarutan polimer ini terhadap air membuat xanthan gum juga memiliki peran penting dalam industri pengeboran dan recovery minyak [1]. Dalam industri minyak, xanthan gum digunakan dalam jumlah besar, biasanya untuk mengentalkan lumpur pengeboran. Cairan ini berfungsi untuk membawa potongan padatan akibat pengeboran kembali ke permukaan. 
Xanthan gum menghasilkan " low end " reologi yang bagus. Ketika sirkulasi berhenti, padatan masih tetap tersuspensi dalam cairan pengeboran. Meluasnya penggunaan pengeboran horizontal dan permintaan untuk kontrol padatan yang dibor telah menyebabkan penggunaannya diperluas. Pada Industri Petroleum, xanthan gum digunakan sebagai cairan pelicin dalam pengeboran sumur minyak, sebagai cairan untuk mengikat dan memisahkan garam-garam dari hasil pengeboran minyak lepas pantai dari cairan petroleum yang diinginkan, sebagai cairan pemecah (fracturing fluid) berbasis air dan untuk mempercepat pengambilan minyak (oil recovery).

Berdasarkan potensi yang dimiliki xanthan gum, banyak manfaat yang dapat kita gunakan. Salah satu faktor yang mempengaruhi pertumbuhan dan pembentukan polimer xanthan gum adalah sumber karbon. Sumber karbon komersial yang biasa digunakan seperti glukosa dan sukrosa cukup mahal sehingga diperlukan subtitusi sumber karbon untuk mengurangi biaya produksi xanthan gum. Untuk itu, produksi skala besar dari xanthan gum perlu dikembangkan sebagai upaya meningkatkan nilai ekonomi masyarakat dan upaya melestarikan lingkungan dengan memanfaatkan limbah padat tapioka sebagai sumber karbon. Limbah padat tapioka berasal dari hasil ampas singkong yang telah diperas. Limbah padat industri tapioka dapat dijadikan sebagai sumber karbon karena masih mengandung pati sebanyak $75 \%$ dari bobot kering yang tidak terekstrak. Limbah ini memiliki kandungan protein yang rendah dan serat yang tinggi. Limbah singkong juga termasuk limbah organik yang banyak mengandung karbohidrat, protein, dan gula seperti glukosa, arabinosa, xilosa, dekstran dan manosa [4].

Kondisi optimum untuk pertumbuhan dan produksi xanthan gum adalah pada $\mathrm{pH}$ netral $(7,0)$ dan suhu yang optimum untuk produksi xanthan gum adalah $28^{\circ} \mathrm{C}$ [5]. Konsentrasi limbah padat singkong yang menghasilkan xanthan gum tertinggi terdapat pada limbah padat dengan konsentrasi gula pereduksi 25,76 $\mathrm{g} / \mathrm{L}$ dan kadar total nitrogen 0,026\% [6,7].
Penelitian scale up proses produksi xanthan gum menggunakan limbah padat tapioka serta karakterisasinya perlu dilakukan untuk memperoleh informasi ilmiah terkait proses produksi serta memanfaatkan limbah padat tapioka sebagai sumber karbon dalam produksi skala industri. Limbah padat tapioka dipilih karena ketersediaannya yang melimpah, harga relatif lebih murah dari sukrosa dan glukosa (sebagai sumber karbon), dan pemanfaatannya yang belum optimal di tengah masyarakat.

Penelitian ini bertujuan untuk memperoleh informasi ilmiah terkait proses produksi (scale up) xanthan gum dengan menggunakan limbah padat tapioka yang dapat oleh Xanthomonas campestris. Penelitian ini juga bertujuan untuk memperoleh informasi ilmiah mengena karakteristik xanthan gum hasil fermentasi limbah padat tapioka oleh bakteri $X$.campestris. Memproduksi xanthan gum pada skala fermentor 20 liter.

\section{METODOLOGI PENELITIAN}

\section{Inokulasi, Peremajaan dan Pembuatan} Kurva Pertumbuhan X.campestris

Sebanyak lima ose bakteri X.campestris (berasal dari koleksi Fakultas Pertanian IPB) dimasukkan ke dalam 200 ml larutan NB steril dan diatur $\mathrm{pH}$ nya menjadi 7. Selanjutnya X.campestris pada NB diinkubasi pada suhu ruang dengan kecepatan agitasi $125 \mathrm{~s} / \mathrm{min}$. Pertumbuhan sel bakteri diamati dengan mengukur Optical Density (OD) pada panjang gelombang $600 \mathrm{~nm}$ selama 20 jam dengan interval waktu 4 jam. Pertumbuhan bakteri pada fase log digunakan untuk proses produksi xanthan gum [8][9].

\section{Preparasi Limbah Padat Singkong}

Limbah padat singkong basah yang digunakan berasal dari industri pembuatan tepung tapioka. Kemudian limbah padat singkong dikeringkan pada suhu $80^{\circ} \mathrm{C}$ selama 24 hingga 48 jam. Ampas singkong yang telah dikeringkan tersebut dihaluskan kembali dengan mesin penggiling dan diayak hingga ukuran 80 mesh. Selanjutnya substrat limbah padat singkong digunakan sebagai sumber karbon perlakuan fermentasi. 


\section{Penetapan Gula Pereduksi Metode Somogyi- Nelson}

Penentuan kadar gula reduksi dengan metode Nelson - Somogyi dibuat larutan standar dengan konsentrasi 2, 4, 6, 8, $10 \mathrm{mg} / 100 \mathrm{ml}$, larutan standar tersebut masing-masing ditambah reagen Nelson Somogyi yang berwarna biru. Setelah ditambahkan reagen Nelson somogyi, larutan yang berwarna biru sampai biru kehijauan tersebut dipanaskan 20 menit, tujuan dari pemanasan ini adalah untuk mempercepat proses reduksi kupri oksida menjadi kupro oksida. Lalu larutan didinginkan sampai $25^{\circ} \mathrm{C}$ supaya reaksi berjalan stabil, karena apabila terlalu panas kemungkinan akan ada komponen senyawa yang rusak atau habis menguap. Kemudian ditambahkan reagen arsenomolibdat, penambahan reagen arsenomolibdat ini bertujuan agar bisa bereaksi dengan endapan kupro oksida. Absorbansi diukur dengan spektrometer.

\section{Produksi Xanthan Gum}

Proses fermentasi dilakukan pada biofermentor dengan metode batch, dimana media fermentasi (nutrien yang dibutuhkan seperti glukosa, ammonia, serta bahan-bahan lain) dimasukkan bersamaan. Sebanyak 5\% $(\mathrm{v} / \mathrm{v})$ NB yang mengandung X.campestris dengan waktu inkubasi 16 jam dimasukkan pada $200 \mathrm{ml}$ media yang berisi urea $5 \mathrm{~g} / \mathrm{L}$, $\mathrm{MgSO}_{4} 1 \mathrm{~g} / \mathrm{L}, \mathrm{NaCl} 1.5 \mathrm{~g} / \mathrm{L}$, dan $\mathrm{KH}_{2} \mathrm{PO}_{4} 2 \mathrm{~g} / \mathrm{L}$, serta limbah padat singkong dengan konsentrasi 10, 20, 30, 40, dan 50 g/L. Setelah diperoleh data pengukuran komposisi limbah padat singkong terbaik, maka dilakukan pula variasi komposisi urea 3 g/L, 4 g/L, 5 g/L,6 g/L, dan 7 g/L dimana konsentrasi limbah padat singkong tetap. Kemudian dilakukan pula variasi komposisi urea dan limbah padat singkong. Fermentasi dilakukan selama 80 jam dengan interval waktu 16 jam. Untuk mengetahui tahap pertumbuhan bakteri, media fermentasi diambil sebanyak $10 \mathrm{ml}$ setiap 5 jam untuk dihitung kadar glukosa dan biomassanya dan hasil pengukuran dituangkan dalam bentuk kurva [10].

\section{Pengukuran Biomassa Sel.}

Pengukuran biomassa sel dilakukan selama 80 jam dengan interval waktu 16 jam. Proses pemisahan dilakukan dengan mengambil
$10 \mathrm{ml}$ media fermentasi lalu disentrifugasi pada kecepatan $10.000 \mathrm{~s} / \mathrm{min}$ selama 30 menit pada suhu $4^{\circ} \mathrm{C}$. Pelet yang dihasilkan dari proses sentrifugasi dilarutkan kembali dengan akuades untuk proses pencucian. Selanjutnya pelet hasil sentrifugasi dikeringkan dalam oven bersuhu $60^{\circ} \mathrm{C}$ selama 2 jam hingga bobotnya konstan. Pengukuran biomassa sel dilakukan membandingkan bobot sel yang telah kering per liter medium kultur sehingga diperoleh biomassa sel dengan satuan g/L [11].

\section{Pengukuran Kadar Rendemen Xanthan Gum.}

Proses pengukuran rendemen xanthan gum dilakukan selama 80 jam dengan waktu interval 16 jam. Sebanyak $10 \mathrm{ml}$ media fermentasi diambil lalu disentrifugasi dengan kecepatan $10.000 \mathrm{~s} / \mathrm{min}$ selama 30 menit dengan suhu $4^{\circ} \mathrm{C}$. Xanthan gum yang terdapat pada supernatan ditambah dengan metanol dengan perbandingan $1 ; 3(\mathrm{v} / \mathrm{v})$. Selanjutnya larutan disimpan pada suhu $5^{\circ} \mathrm{C}$ selama 24 jam kemudian disentrifugasi kembali dengan kecepatan $10.000 \mathrm{~s} / \mathrm{min}$ selama 30 menit dengan suhu $4^{\circ} \mathrm{C}$. selanjutnya pelet hasil sentrifugasi ditambah sedikit air dan dikeringkan dalam oven bersuhu $50^{\circ} \mathrm{C}$ sampai bobotnya konstan lalu ditimbang [12].

\section{HASIL DAN PEMBAHASAN Pertumbuhan Bakteri Xanthomonas campestris}

Pembuatan kurva pertumbuhan ini bertujuan untuk mengetahui pola dan waktu tumbuh bakteri. Hasil kurva pertumbuhan Xanthomonas campestris menunjukkan absorbansi awal yang terukur pada jam ke-0 sebesar 0,0030. Absorbansi pada jam ke-4 mengalami sedikit peningkatan yaitu 0,0060 . Absorbansi meningkat secara signifikan pada jam ke-8, jam ke-12 dan jam ke-16 dengan absorbansi yang terukur yaitu sebesar 0,0570 , 0,3210 , dan 0,7050. Absorbansi pada jam ke20 menjadi konstan dengan absorbansi yang terukur yaitu sebesar 0,7070. Hasil kurva menunjukkan pada jam ke-8 hingga jam ke-16 merupakan fase eksponensial.

Bakteri mengalami fase ekponensial atau fase log yang terjadi pada jam ke-8 hingga jam 
ke-16. Pada fase ini bakteri mulai membelah sehingga terjadi peningkatan absorbansi yang sangat signifikan. Selanjutnya pertumbuhan bakteri masuk pada fase stasioner yang terjadi setelah jam ke-16. Pada fase ini media tumbuh bakteri mulai habis sehingga banyak bakteri yang mengalami lisis sel yang ditandai dengan nilai absorbansi yang konstan.

Berdasarkan kurva pertumbuhan, fase log pada penelitian ini sesuai dengan penelitian [8] yang terjadi pada jam ke-12 hingga jam ke-16. Fase log berakhir setelah 16 jam inkubasi. Jumlah sel yang hidup pada fase ini merupakan jumlah sel yang hidup optimal dan memiliki aktivitas yang sangat aktif dalam mengkonversi substrat menjadi xanthan gum.

Penumbuhan Xanthomonas campestris pada media NB dapat membantu menyiapkan stok bakteri untuk media fermentasi dengan jumlah sel yang tinggi namun belum memasuki tahap produksi xanthan gum [13]. Pertumbuhan sel yang teramati berbentuk sigmoid yang terdiri atas tiga fase yaitu fase lag, fase log, dan fase stasioner. Fase lag merupakan fase awal pertumbuhan bakteri sehingga hanya teramati sedikit pembelahan sel yang ditandai dengan rendahnya peningkatan absorbansi yang terjadi pada jam ke-0 hingga jam ke-8. Pada fase ini sel aktif melakukan metabolisme seperti sintesis enzim dan organel untuk mempersiapkan pembelahan sel [14].

Fase adaptasi merupakan tahap penyesuaian bakteri terhadap lingkungan baru. Fase adaptasi ini terjadi ketika bakteri mengalami perubahan medium serta lingkungannya, yaitu dari medium NA ke medium NB lalu ke medium limbah padat singkong. Lamanya fase adaptasi dipengaruhi oleh beberapa faktor seperti medium, lingkungan pertumbuhan dan jenis inokulum. Jika medium dan lingkungan pertumbuhan sama seperti medium dan lingkungan sebelumnya, maka tidak diperlukan waktu adaptasi tetapi jika nutrien yang tersedia dan lingkungan yang baru berbeda dengan sebelumnya maka diperlukan waktu penyesuaian untuk menyintesis enzimenzim [15].

Pada fase eksponensial kecepatan pertumbuhan sangat dipengaruhi oleh medium tempat tumbuhnya seperti kandungan nutrien, $\mathrm{pH}$, suhu, dan kelembaban udara. Setelah jam ke-16 hingga jam ke-20 bakteri memasuki fase stasioner. Jumlah populasi pada fase ini tetap karena jumlah sel yang tumbuh sama dengan jumlah sel yang mati. Ukuran sel pada fase ini menjadi lebih kecil karena sel tetap membelah meskipun jumlah nutrien semakin habis. Pada fase ini sel-sel lebih tahan terhadap keadaan ekstrim seperti panas, dingin, radiasi, dan pengaruh bahan-bahan kimia [16].

\section{Produk Xanthan Gum Hasil Fermentasi}

Pengukuran rendemen xanthan gum dilakukan pada jam ke-16 hingga jam ke-80. Biosintesis xanthan gum terjadi seiring dengan pertumbuhan bakteri dari fase eksponensial selama 72 jam awal hingga fase stasioner. Penambahan waktu 8 jam pada penelitian ini bertujuan untuk melihat pola pembentukan xanthan gum setelah fase stasioner [17]. Biokonversi limbah padat tapioka menjadi xanthan gum diawali dengan proses hidrolisis limbah padat tapioka untuk mendapatkan gula. Proses pembentukan xanthan gum membutuhkan gula sebagai sumber karbon dalam proses fermentasi oleh bakteri Xanthomonas campestris.

Beberapa variabel yang yang mempengaruhi rendemen xanthan gum meliputi komposisi media kultur, temperatur, $\mathrm{pH}$, dan transfer oksigen [2]. Kondisi yang optimal untuk pertumbuhan dan pembentukan xanthan gum adalah $\mathrm{pH}$ netral dan suhu yang optimal untuk pembentukan xanthan gum adalah $28^{\circ} \mathrm{C}$ [5]. Untuk mempertahankan $\mathrm{pH}$ netral, maka ditambahkan fosfat. Penambahan fosfat selain sebagai buffer juga merupakan mikronutrien untuk proses pertumbuhan dan pembentukan xanthan gum [9].

Rendemen xanthan gum tertinggi terdapat pada komposisi limbah padat tapioka dengan konsentrasi 50 g/L (5\%) dan nitrogen 5\% yaitu sebesar $69 \%$ sedangkan bobot terendah terdapat pada komposisi limbah padat tapioka $10 \mathrm{~g} / \mathrm{L}$ (1\%) dan nitrogen 5\% yaitu sebesar 8\% (Gambar 1 dan 2). Selanjutnya terus mengalami penurunan dari jam ke-32 hingga jam ke-80, kecuali komposisi limbah padat tapioka 5\% dan nitrogen 5\% di jam ke-32 dan ke-64 juga 
komposisi limbah padat tapioka 5\% dan nitrogen 4\% di jam ke-32 serta komposisi limbah padat tapioka 5\% dan nitrogen $6 \%$ di jam ke-64 mengalami kenaikan.

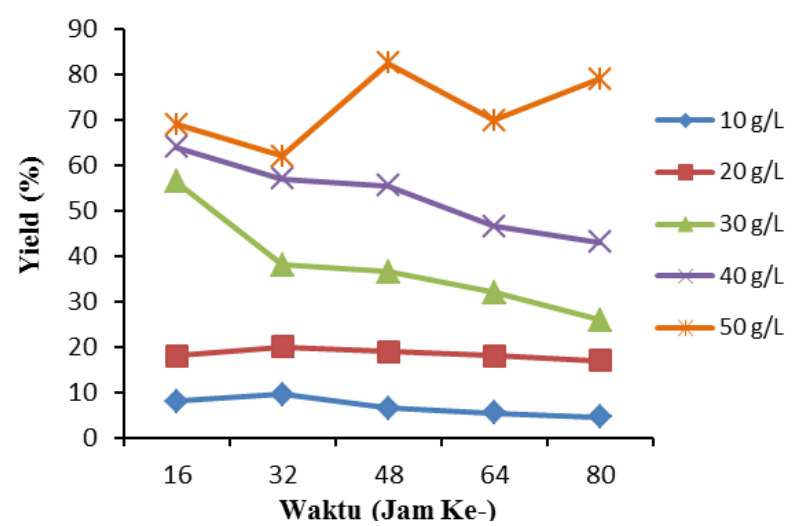

Gambar 1. Kurva Hasil Pengukuran Xanthan Gum (\%) Pada Variasi Konsentrasi C dan Konsentrasi N Tetap

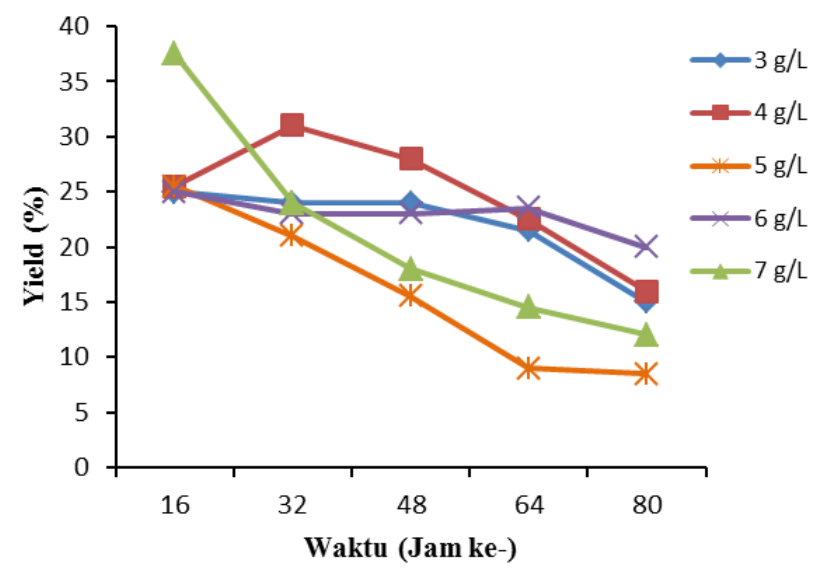

Gambar 2. Kurva Hasil Pengukuran Xanthan Gum (\%) pada Variasi Konsentrasi $\mathrm{N}$ dan Konsentrasi C Tetap

Hasil xanthan gum yang diperoleh dari proses fermentasi pada keadaan konsentrasi nitrogen tetap, menunjukkan peningkatan seiring bertambahnya konsentrasi limbah padat tapioka. Hal ini dikarenakan dalam media fermentasi masih terkandung nutrien yang cukup untuk menunjang pertumbuhan dan produksi xanthan gum. Rata-rata terjadi penurunan rendemen xanthan gum seiring bertambahnya waktu. Hal ini karena jumlah nutrien yang semakin sedikit menyebabkan kompetisi pada bakteri untuk memperoleh sumber karbon, sehingga sel menyusut dan produksi xanthan gum menurun [16].
Selain faktor $\mathrm{pH}$ dan nutrien, suplai oksigen dalam erlenmeyer (2L) kemungkinan kurang mencukupi untuk pertumbuhan bakteri, sehingga kekurangan oksigen menyebabkan berkurangnya produksi energi untuk pertumbuhan sekaligus mengalihkan alokasi penggunaan substrat untuk pemeliharaan sel, sehingga mengurangi produksi xanthan gum [18].

Suplai oksigen yang berkesinambungan dalam fermentor beragitasi dapat meningkatkan produksi xanthan gum. Oksigen merupakan syarat mutlak untuk pertumbuhan mikroba aerob. Faktor lain yang berpengaruh adalah masih terdapatnya massa produk yang tidak terlepas dari massa selnya pada saat proses kematian sel dan pada saat sentrifugasi, akibatnya xanthan gum yang dihasilkan ikut terbuang [3].

Agitasi yang tepat pada medium fermentasi meningkatkan laju biosintesis xanthan gum. Agitasi yang tinggi ( $>500 \mathrm{~s} / \mathrm{min}$ ) dapat menurunkan jumlah produksi xanthan gum karena sel mengalami stres, sedangkan agitasi yang rendah akan mengurangi transfer oksigen. Hal ini dikarenakan adanya peningkatan viskositas media akibat pertambahan biomassa sel dan xanthan gum [5].

Pembentukan xanthan gum rata-rata tertinggi pada jam ke-16. Pada penelitian ini jumlah rendemen xanthan gum yang terukur pada konsentrasi $\mathrm{N}$ tetap yaitu $8 \mathrm{~g} / \mathrm{L}$ untuk konsentrasi limbah padat tapioka 1\%, 18g/L untuk konsentrasi limbah padat tapioka $2 \%$, 56,5g/L untuk konsentrasi limbah padat tapioka 3\%, 64g/L untuk konsentrasi limbah padat tapioka 4\%, dan 69g/L untuk konsentrasi limbah padat tapioka 5\% lebih tinggi dari penelitian [19] yaitu 16,95 g/L. Sedangkan pada konsentrasi $\mathrm{C}$ tetap jumlah rendemen xanthan gum terukur rata-rata pada jam ke-16 yaitu seberar $25 \mathrm{~g} / \mathrm{L}$. Hasil ini lebih tinggi daripada [11] yaitu sebesar 3,6 g/L.

Hasil pengukuran tersebut kemudian diolah dengan menggunakan Respon Surface Method (Metode Permukaan Respon) [20]. Variabel respon pada penelitian ini adalah $Y$ (komposisi $\mathrm{C}$ dan $\mathrm{N}$ optimum untuk produksi xanthan gum). Variabel bebas yang digunakan adalah $x_{1}$ yaitu konsentrasi limbah padat tapioka 
sebagai sumber karbon (C) dalam satuan gram per liter (10 g/L, $20 \mathrm{~g} / \mathrm{L}, 30 \mathrm{~g} / \mathrm{L}, 40 \mathrm{~g} / \mathrm{L}, 50 \mathrm{~g} / \mathrm{L})$ dan $x_{2}$ yaitu konsentrasi urea sebagai sumber nitrogen $(\mathrm{N})$ dalam satuan gram per liter $(3 \mathrm{~g} / \mathrm{L}$, $4 \mathrm{~g} / \mathrm{L}, 5 \mathrm{~g} / \mathrm{L}, 6 \mathrm{~g} / \mathrm{L}, 7 \mathrm{~g} / \mathrm{L})$.

Level-level eksperimen pada masingmasing variabel independen dikodekan sedemikian hingga level rendah berhubungan dengan -1 dan level tinggi berhubungan dengan 1 untuk mempermudah perhitungan. Desain pada eksperimen ini menggunakan dua variabel independen, sehingga nilai rotatabilitasnya = $\left(2^{2}\right)^{1 / 4}=1,414$. Oleh karena itu nilai $\pm 1,41421$ termasuk nilai yang digunakan untuk pengkodean.

Uji RSM pada 16 jam pertama memperoleh nilai $\mathrm{F}$ sebesar 20,045 pada model. Hanya sekitar 0,0005\% kemungkinan model yang diperoleh mengalami galat atau gangguan (prob $>$ F). Nilai prob $>$ F kurang dari nilai $\alpha(5 \%)$ menunjukkan bahwa masing-masing variabel (konsentrasi karbon dan nitrogen) memiliki perbedaan yang signifikan dalam model $(Y=$ $0.0147 A+0.0242 B-0.018 A B-0.1107 A^{2}-$ $\left.0.0932 B^{2}\right)$. Koefisien determinasi $\left(\mathrm{R}^{2}\right)$ yang diperoleh sebesar 0,93. Hal itu menunjukkan bahwa model dapat menjelaskan 93\% keragaman dalam produksi xanthan gum oleh bakteri Xanthomonas campestris. Uji RSM pada 16 jam ke dua memperoleh nilai $F$ sebesar 87,638 pada model. Hanya sekitar kurang dari 0,0001\% kemungkinan model yang diperoleh mengalami galat atau gangguan (prob $>F$ ). koefisien determinasi $\left(\mathrm{R}^{2}\right)$ yang diperoleh sebesar 0,98. Hal itu menunjukkan bahwa model dapat menjelaskan 98\% keragaman dalam produksi xanthan gum oleh bakteri Xanthomonas campestris. Uji RSM pada 16 jam ke tiga memperoleh nilai $\mathrm{F}$ sebesar 52,114 pada model. Hanya sekitar kurang dari 0,0001\% kemungkinan model yang diperoleh mengalami galat atau gangguan (prob $>F$ ). Koefisien determinasi $\left(\mathrm{R}^{2}\right)$ yang diperoleh sebesar 0,97. Hal itu menunjukkan bahwa model dapat menjelaskan 97\% keragaman dalam produksi xanthan gum oleh bakteri Xanthomonas campestris. Uji RSM pada 16 jam ke empat memperoleh nilai F sebesar 7,7235 pada model. Hanya sekitar 0,0091\% kemungkinan model mengalami galat atau gangguan (prob $>F$ ).
Koefisien determinasi $\left(\mathrm{R}^{2}\right)$ yang diperoleh sebesar 0,85. Hal itu menunjukkan bahwa model dapat menjelaskan $85 \%$ keragaman dalam produksi xanthan gum oleh bakteri Xanthomonas campestris. Uji RSM pada 16 jam ke lima memperoleh nilai $\mathrm{F}$ sebesar 8,8215 pada model. Hanya sekitar 0,0062\% kemungkinan model mengalami galat atau gangguan (prob $>F)$. Koefisien determinasi $\left(\mathrm{R}^{2}\right)$ yang diperoleh sebesar 0,86. Hal itu menunjukkan bahwa model dapat menjelaskan 86\% keragaman dalam produksi xanthan gum oleh bakteri Xanthomonas campestris. Berdasarkan data dan grafik permukaan 3D. Dapat disimpulkan bahwa disetiap 16 jam respon maksimum adalah mendekati titik pusat $(0,0)$. Model memprediksi produksi xanthan gum maksimum pada konsentrasi limbah padat tapioka 31,8 g/L dan nitrogen 5g/L. Hal ini sesuai dengan hasil penelitian ini, rata-rata hasil produksi xanthan gum tertinggi pada kombinasi konsentrasi limbah padat tapioka sebagai sumber karbon yaitu $30 \mathrm{~g} / \mathrm{L}$ dan nitrogen $5 \mathrm{~g} / \mathrm{L}$ dengan hasil yang relatif konstan pada lima kali pengulangan.

\section{Uji Rheologi Xanthan Gum}

Xanthan gum sangatlah pseudoplastik. Ketika shear stress meningkat, maka viskositas akan menurun. Xanthan gum tidak bersifat thixotropic sampai tingkat yang signifikan. Pseudoplastisitas hasil dari molekul dengan berat molekul yang tinggi, yang membentuk agregat molekul kompleks melalui ikatan hidrogen dan ikatan polimer. Konformasi yang teratur dan kaku menyumbang viskositas yang tinggi pada tingkat shear yang rendah. Penipisan pseudoplastisitas hasil dari disagregasi dari polimer ini dan penelusuran molekul monomer ke arah gaya shear. Konformasi xanthan gum distabilkan oleh ikatan hidrogen tetapi tidak stabil dengan adanya tolakan antara kelompok yang bermuatan negatif di sisi rantai yang saling tumpang tindih. Konsentrasi elektrolit yang rendah meningkatkan keteraturan konformasi xanthan gum dengan mengurangi tolakan elektrostatik antara anion karboksilat pada sisi trisakarida. Struktur dipertahankan dengan kenaikan suhu, hal ini yang menjelaskan 


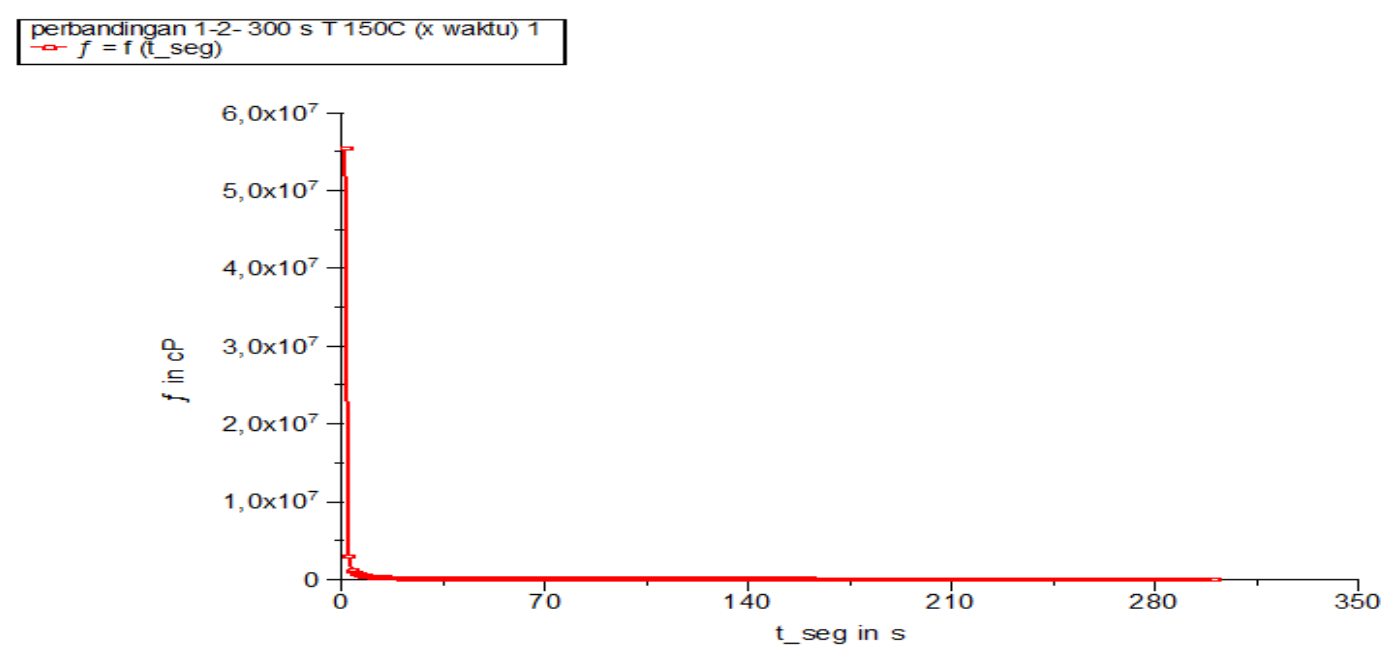

Gambar 3. Kurva Hubungan Viskositas Terhadap Waktu pada Suhu $150^{\circ} \mathrm{C}$

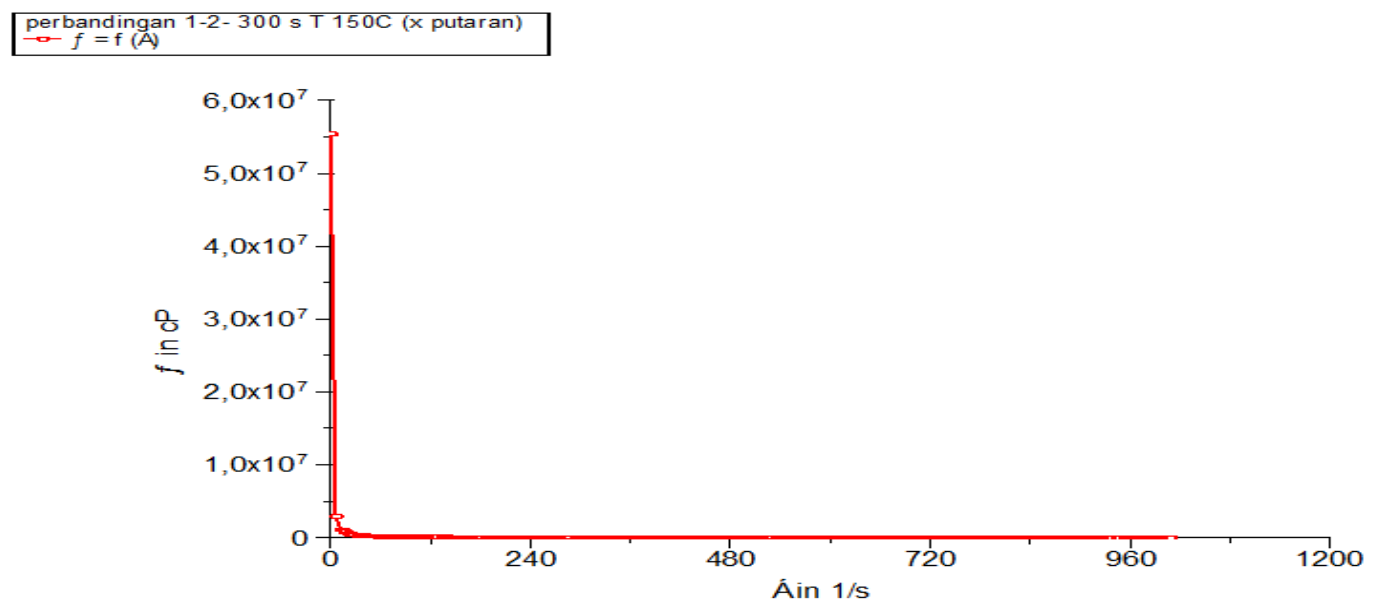

Gambar 4. Kurva hubungan viskositas terhadap shear pada suhu $150^{\circ} \mathrm{C}$

mengapa viskositas xanthan gum tidak peka terhadap perubahan suhu.

Berdasarkan Gambar 3, tidak terlihat perubahan viskositas xanthan gum yang signifikan terhadap fungsi waktu pada suhu $120^{\circ} \mathrm{C}$ dan $150^{\circ} \mathrm{C}$. hal ini dikarenakan konformasi yang teratur dan kaku sehingga memungkinkan terjadinya peregangan ketika ada pengaruh panas, dan regangan kembali ke keadaan semula ketika panas itu hilang.

Pengaruh shear terhadap penurunan viskositas xanthan gum cukup signifikan. Pada tingkat shear yang rendah xanthan gum memiliki kira-kira limabelas kali viskositas dari guar gum dan secara signifikan viskositasnya lebih tinggi dari karboksimetil-selulosa (CMC). Hal ini menjelaskan kinerja superior xanthan gum dalam menstabilkan suspensi. Konformasi yang teratur dan kaku menyumbang viskositas yang tinggi pada tingkat shear yang rendah.
Penipisan pseudoplastisitas hasil dari disagregasi dari polimer ini dan penelusuran molekul monomer ke arah gaya shear. Konformasi xanthan gum distabilkan oleh ikatan hidrogen tetapi tidak stabil dengan adanya tolakan antara kelompok yang bermuatan negatif di sisi rantai yang saling tumpang tindih.

\section{Uji FTIR Xanthan Gum}

Xanthan gum yang dihasilkan dari fermentasi limbah padat tapioka (Gambar 5) juga memiliki karakteristik yang hampir sama dengan xanthan gum komersial di pasaran. Hal ini sesuai menurut [12] bahwa xanthan gum komersial menunjukkan peak puncak gugus hidroksil pada 3386, gugus karbonil pada 1627, gugus karboksil pada 1529 dan gugus asetat pada 1160. 


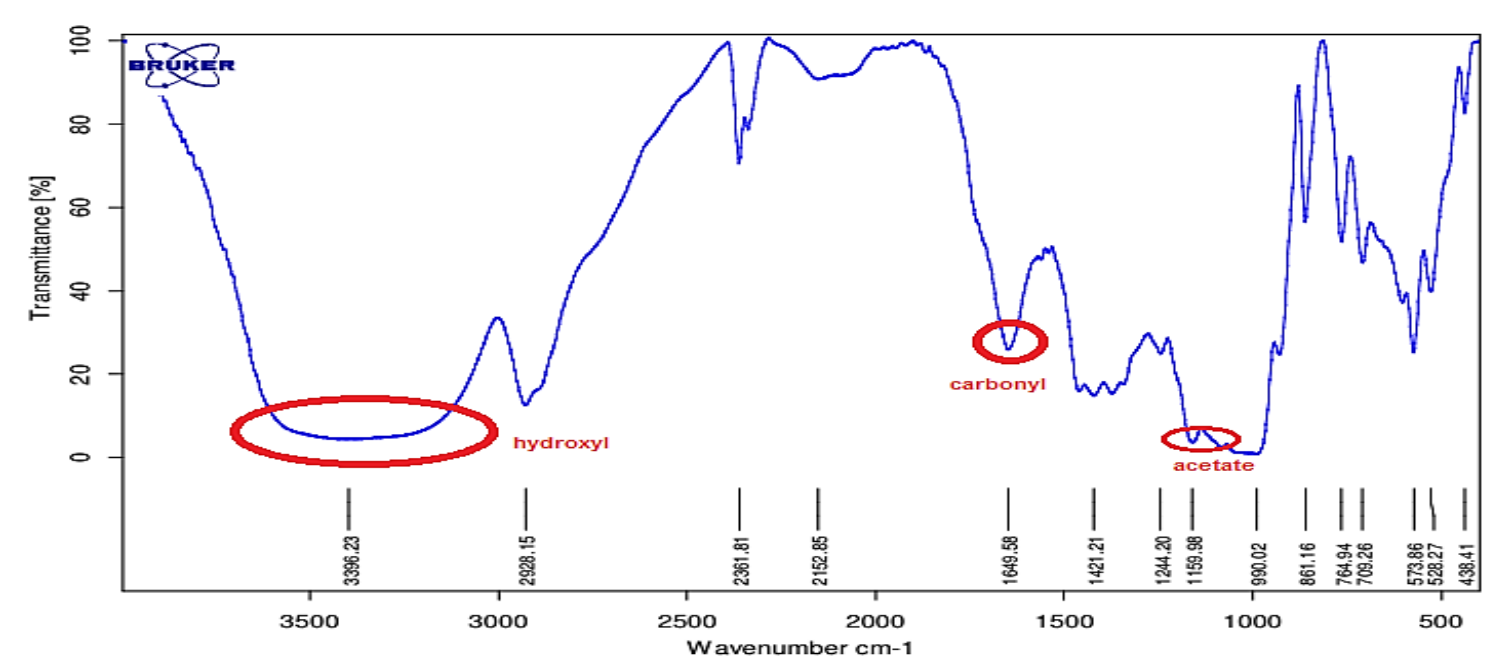

Gambar 5. Spektrum FTIR Xanthan Gum Hasil Fermentasi Limbah Padat Tapioka

\section{KESIMPULAN}

Xanthan gum dapat diperoleh dari hasil fermentasi limbah padat tapioka sebagai sumber karbon dan urea sebagai sumber nitrogen oleh bakteri Xanthomonas campestris. Rendemen xanthan gum tertinggi terdapat pada komposisi limbah padat tapioka dengan konsentrasi $50 \mathrm{~g} / \mathrm{L}$ dan urea 5g/L yaitu sebesar 69\%. Prediksi kondisi optimum untuk memproduksi xanthan gum oleh Xanthomonas campestris berdasarkan model persamaan yang diperoleh $Y=0.0147 A+$ $0.0242 B-0.018 A B-0.1107 A^{2}-0.0932 B^{2}$ yaitu konsentrasi sumber karbon $30 \mathrm{~g} / \mathrm{L}$ dan nitrogen $5 \mathrm{~g} / \mathrm{L}$. Tidak ada perbedaan yang signifikan antara nilai prediksi dan hasil verifikasi yang menunjukkan bahwa model mapan dalam penelitian ini layak dan efektif. Hasil uji rheology menunjukkan karakteristik produk yang cukup baik yang didukung oleh uji FTIR yang menunjukkan spektrum xanthan gum hasil penelitian tidak berbeda dibandingkan dengan produk komersil.

\section{DAFTAR PUSTAKA}

[1] Gracia-Ochoa, Santos V E, Casas J A, Gomez E. 2000. Xanthan gum : Production, Recovery, and Properties. Biotechnology Advances. Vol. 18: PP. 549-579. Elsevier Science.

[2] Faria S, Viera P, Risende M, Riberio E, Cardoso V. 2010. Aplication of model using the phenomenological approach for prediction og growth and xanthan gum production with sugar cane broth in batch process. LWT Food Science Technology. Vol. 43: PP. 498-506. Elsevier Science.

[3] Faria S, Carmen Lucia de Oliveira Petcowicz, Sergio Antonio Lemos de Morais, Manuel Gonzalo Hernandez Terrones, Miriam Maria de Resenole, Francisca Pessoa de Franca, Vicelma Luiz Cardoso. 2011. Characterization of xanthan gum produced from sugar cane broth. Carbohydrate Polymers J. V 86 : PP 469-476.

[4] Retnowati, D dan Sutanti. 2009. Pemanfaatan limbah padat ampas singkong dan lindur sebagai bahan baku pembuatan etanol. [Skripsi]. Malang (ID): Universitas Brawijaya

[5] Mudoi P, Bharali P, Konwar B. 2013. Study on the effect of $\mathrm{pH}$, temperature and the aeration on the cellular growth and xanthan production by Xanthomonas campestris using waste residual molases. Journal of Bioprocessing \& Biotechniques. No. 3(Vol. 2): PP. 1-6. Open Access.

[6] Afidah AC. 2016. Optimasi Konsentrasi Limbah Cair Tahu Untuk Produksi Gum Xanthan oleh Xanthomonas campestris. [Skripsi], Bogor. IPB Bogor

[7] Gomashe A V, Dharmik P G, Fuke P S. 2013. Optimization and Production of xanthan gum by Xanthomonas campestris NRRL-B-1499 from sugar beet molasses. International Journal of Engineering and 
Science. No. 2 (Vol. 5): PP. 52-55. Elsevier Science.

[8] Jackson M, Frymier J, Wilkinson B, Zorner P, Evans. 1998. Growth requirements for production of stable cell of the bioherbicidal bacterium Xanthomonas campestris. Journal of Industrial Microbiology and Biotechnology. No. 21: PP. 237-241. SCImago.

[9] Kalogiannis S, Iakovidou G, LiakopoulouKyriakides M, Kyriakidis D, Skarocis G. 2003. Optimization of xanthan gum production by Xanthomonas campestris grow in molasses. Process Biochemistry. No. 39(Vol. 2): PP. 249-256. Elsevier Science.

[10] Carignatto, C. R. R., Kassandra S M O, Valeria M G de Lima, Pedro de Olivia Neto. 2011. New culture medium to xanthan production by Xanthomonas campestris pv. campestris. Indian Journal of Microbiology. No. 51(Vol. 3):PP. 283288. Springer.

[11] Palaniraj A, Jayaraman V. 2011. Production, recovery and applications of xanthan gum by Xanthomonas campestris. Journal of Food Engineering - Elsevier. Vol. 106: PP. 1-12. Elsevier Science.

[12] Gilani S, Najafpour G, Heydarzadeh H, Zare H. 2011. Kinetic models for xanthan gum production using Xanthomonas campestris from molasses. Chemical Industry \& Chemical Engineering Quarterly. No. 17 (Vol. 2): PP. 179-187. Association of the Chemical Engineers.

[13] Cintia R R C, Kassandra S M O, Valeria M G de Lima, Perdore Olivia Neto. 2011. New culture medium to xanthan production by Xanthomonas campestris pv. campestris. Indian Journal Microbiology. No. 51(Vol. 3): PP. 283288. Scientific Publishers.

[14] Jeeva S, Selva Mohan T, Palavesam A, Packia Lekshmi M C J, and Raja Brindha J. 2011. Production and optimization study of a novel extracellular polysaccharide by wild-type isolates of Xanthomonas campestris. Journal of Microbiology and Biotechnology Research . 1(4) : 175-182. Open Access.

[15] Irianto K. 2010. Mikrobiologi : Menguak Dunia Mikroorganisme Jilid I. Bandung (ID) : Yrama Widya.

[16] Panjaitan D, Ketut IS, Sritamin M. 2014. Uji Keefektivan ekstrak beberapa biji tanaman untuk menghambat pertumbuhan bakteri bercak daun (Xanthomonas campestris) padan tanaman tomat. EJournal Agroekoteknologi Tropika. No. 3(Vol. 2): PP. 89-96. Universitas Udayana.

[17] El-Enshasy H, Then C, Othman NZ, Al Homosany H, Sabry M, Sarmidi MR, Aziz RA. 2011. Enhanced xanthan production process in shake flasks and pilot scale bioreactors using industrial semi-defined medium. African Journal of Biotechnology. No. 10 (Vol. 6): PP. 10291038.

[18]. Palennari M, Rante H. 2009. Kajian pembentukan gum xanthan dari limbah padat sagu oleh Xanthomonas campestris. Bionature. 10(1) ; 24-28. Open Journal Sistemes

[19] Quinliang L, Wei Y, Kedi Y, Yanxuan W, Ji-liang T. 2012. Xanthan gum production by Xanthomonas campestris pv.Campestris 8004 using cassava starch as carbon source. Afr J Biotechnol 11 (3) : 13809-13813.

[20] Box, G. E. P., dan Draper N. R. 1987. Empirical model-building and response surfaces. New York : John Wiley \& Sons, Inc. 